\title{
DIVERSITY AND GENETIC RELATEDNESS AMONG GENOTYPES OF Vitis spp. USING MICROSATELLITE MOLECULAR MARKERS ${ }^{1}$
}

\author{
PATRÍCIA COELHO DE SOUZA LEÃO², COSME DAMIÃO CRUZ ${ }^{3}$ \\ SÉRGIO YOSHIMITSU MOTOIKE ${ }^{3}$
}

\begin{abstract}
The purpose of this research was to study the genetic diversity and genetic relatedness of 60 genotypes of grapevines derived from the Germplasm Bank of Embrapa Semiárido, Juazeiro, BA, Brazil. Seven previously characterized microsatellite markers were used: VVS2, VVMD5, VVMD7, VVMD27, VVMD3, ssrVrZAG79 and ssrVrZAG62. The expected heterozygosity $\left(\mathrm{H}_{\mathrm{e}}\right)$ and polymorphic information content (PIC) were calculated, and the cluster analysis were processed to generate a dendrogram using the algorithm UPGMA. The $\mathrm{H}_{\mathrm{e}}$ ranged from $81.8 \%$ to $88.1 \%$, with a mean of $84.8 \%$. The loci VrZAG79 and VVMD7 were the most informative, with a PIC of 87 and $86 \%$, respectively, while VrZAG62 was the least informative, with a PIC value of $80 \%$. Cluster analysis by UPGMA method allowed separation of the genotypes according to their genealogy and identification of possible parentage for the cultivars 'Dominga', 'Isaura', 'CG 26916', 'CG28467' and 'Roni Redi'.
\end{abstract}

Index terms: Grape, multivariate analysis, genealogy, SSR.

\section{DIVERSIDADE E RELAÇÕES GENÉTICAS ENTRE GENÓTIPOS DE Vitis spp. UTILIZANDO MARCADORES MOLECULARES MICROSSATÉLITES}

RESUMO- O presente trabalho teve como objetivo estudar a diversidade genética e as relações de parentesco de 60 genótipos de videira procedentes do Banco de Germoplasma da Embrapa Semiárido, Juazeiro-BA. Sete marcadores microssatélites previamente caracterizados foram utilizados: VVS2, VVMD5, VVMD7, VVMD27, VVMD3, ssrVrZAG79 e ssrVrZAG62. Foram calculadas a heterozigosidade esperada ( $\mathrm{H}_{\mathrm{e}}$ ), conteúdo de informação polimórfica (PIC), e as análises de agrupamento foram processadas para gerar um dendograma, utilizando-se do algoritmo UPGMA. $\mathrm{A}_{\mathrm{e}}$ variou de 81,8 a $88,1 \%$, com média de $84,8 \%$. Os lócus VrZAG79 e VVMD7 foram os mais informativos, com PIC de 87 e $86 \%$, respectivamente, enquanto VrZAG62 foi o menos informativo, com um valor de PIC de $80 \%$. A análise de agrupamento pelo método UPGMA permitiu separar os genótipos de acordo com sua genealogia e identificar possíveis parentais para as cultivares 'Dominga', 'Isaura', 'CG 26916', 'CG28467' e 'Roni Redi'.

Termos para indexação: Uva, análise multivariada, genealogia, SSR. 


\section{INTRODUCTION}

The development of new grapevine cultivars adapted to Brazilian tropical and subtropical conditions has been one of the main objectives of genetic breeding programs in the country. At EMBRAPA Semiárido, grapevine breeding studies are in an initial phase, and, in most recent decades, research efforts have been concentrated on morphoagronomic enrichment and characterization of the genotypes of the Germplasm Bank (BORGES et al. 2008; LEÃO et al., 2010; LEÃO et al., 2011). This collection has begun in 1965 with cultivars collected in the Northeast region and later expanded with others imported from FAO in Italy; Instituto Agronômico de Campinas, in São Paulo; and Embrapa Uva e Vinho, in Rio Grande do Sul. It currently has 261 accessions, with most of the species being Vitis vinifera $\mathrm{L}$.

Most of the grapevine cultivars are ancient and were derived from different processes, such as differentiation from wild grapevines, spontaneous crosses between wild grapevines and cultivars or crosses between cultivars. Ease of asexual propagation gave rise to an estimated number of 14,000 cultivars, for different purposes: fresh consumption, raisins, juices and wine, with the number of grapevine cultivars maintained in germplasm collections being estimated at around 10,000 (ALLEWELDT and DETTWEILER, 1994). Older wild cultivars involved in natural crosses were not able to be identified since they no longer exist naturally, but many parent species are still cultivated or are preserved in collections. Through the use of molecular methods, these parent cultivars and their descendents may be recognized, allowing the study of their geographic origin and evolutionary history.

The use of microsatellite markers has allowed reconstruction of pedigrees of innumerable economically important grapevine cultivars, such as the discoveries that 'Cabernet Sauvignon' is a descendent of 'Cabernet Franc' and 'Sauvignon Blanc' (BOWERS and MEREDITH, 1997), 'Durif', known in California as 'Petit Syrah' (MEREDITH et al., 1999), resulted from the crossing of 'Peloursin' $X$ 'Syrah', and 'Muscat de Hamburgo' is a descendent of 'Moscato de Alexandria' and 'Schiava Grossa' (CRESPAN, 2003).

The purpose of this paper was to study the genetic diversity and genetic relatedness of 60 genotypes belonging to the grapevine Germplasm Bank of Embrapa Semiárido in Petrolina, PE.

\section{MATERIAL AND METHODS}

\section{Plant matter}

A group of 60 grapevine accessions were assessed, including 33 hybrids, 22 accessions of the species Vitis vinifera L., and five accessions of unknown origin. The accessions are part of the Germplasm Bank of Embrapa Semiárido, located in Juazeiro, state of Bahia, Brazil ( $9^{\circ} 24^{\prime}$ 'S, 40 $26^{\circ} \mathrm{W}$, and $365.5 \mathrm{~m}$ of altitude) and they are selected based on their importance for grape breeding and on previous studies (LEÃO et al., 2010; 2011).

\section{DNA extraction and amplification conditions}

Genomic DNA was extracted from young expanded leaves collected from the apex of shoots, as described by Lodhi et al. (1994). Vines were 8 years at the time to collect the samples. The leaves were homogenized by means of a mechanical homogenizer Homes 6 (Bioreba, Longmont, CO). In the final stage, the pellets were suspended in a $1 \mathrm{X}$ Tris EDTA buffer solution and stored at $-20^{\circ} \mathrm{C}$. The integrity of the DNA was verified in $0.8 \%$ agarose gel stained with ethidium bromide.

Seven previously characterized microsatellite markers were used: VVS2 (Thomas e Scott, 1993), VVMD5, VVMD7, VVMD27, VVMD31 (BOWERS et al. 1996; BOWERS et al. 1999), ssrVrZAG79 and ssrVrZAG62 (SEFC et al. 1999). They were chosen as being most recommended for characterization of cultivars in the grapevine germplasm collections (THIS et al., 2004). One of the primers of each pair was labeled at the 5' end with fluorescent dyes such as 6-FAM (blue), HEX (yellow) or NED (green) (Applied Biossystems).

Amplifications were performed in a final reaction volume of $10 \mu \mathrm{l}$ containing $2.5 \mathrm{ng} / \mu \mathrm{l}$ DNA, 10 pmoles of each primer, $2.5 \mathrm{mM}$ of deoxynucleotides mix (Applied Biossystems); $1 \mu \mathrm{L}$ of Gold 10X buffer (Applied Biossystems); $2 \mathrm{mM} \mathrm{MgCl}$ (Applied Biossystems) and 0.5 units of AmpliTaq Gold DNA polymerase (Applied Biossystems).

The PCR (polymerase chain reaction) was performed in a thermocycler PTC-100 (MJ Researcher) using a single program for all the primers. The amplification program consisted of an initial stage of 5 minutes at $95^{\circ} \mathrm{C}$, followed by 35 cycles of 30 seconds at $95^{\circ} \mathrm{C}, 45$ seconds at $60^{\circ} \mathrm{C}$ and 1 minute at $72^{\circ} \mathrm{C}$ and a final extension stage of 7 minutes at $72^{\circ} \mathrm{C}$.

The amplifications were confirmed in $2 \%$ agarose gel stained with ethidium bromide $(10 \mathrm{mg} /$ $\mathrm{mL})$. The PCR products were denatured at $94^{\circ} \mathrm{C}$ for 
2 minutes and then applied in 6\% acrylamide gel, performing electrophoresis in a DNA sequencer model ABI 377 (PE/Applied Biosystems).

The sizes of the alleles were assessed based on comparison with the known internal size standard Genescan Rox 500 (Applied Biosystems) and four grapevine cultivars (Carignane, Riesling, Thompson Seedless and Chardonnay), whose allelic profiles are known as database of Foundation Plant Service/ USDA and University of California at Davis, to allow comparison of the allelic size profiles obtained. The individuals were genotyped using the software GeneScan $^{\mathrm{TM}}$ version 3.1 and Genotyper ${ }^{\mathrm{TM}}$ version 2.5.2. (PE/Applied Biosystems).

\section{Statistical analyses}

The expected heterozygosity $\left(H_{e}\right)$ was calculated according to the formula: $H_{e}=1-\sum p_{i}^{2}$, where $p_{i}$ is the frequency of the allele $i$ th for the locus studied (Nei, 1987). The polymorphic information content (PIC) was calculated as $1-\sum p_{i}^{2}-\sum \sum 2 p_{i}^{2}$ $p_{j}^{2}$, where $p_{i}$ is equal to the frequency of the ith allele and $p_{i}$ is the frequency of the $(i+1)$ th allele (BOTSTEIN et al., 1980). Dissimilarity matrices were obtained using the arithmetic complement of the weighted index given by:

$$
D_{i i^{\prime}}=1-\frac{1}{2} \sum_{j=1}^{L} p_{j} c_{j}
$$

in which: $\mathrm{L}=$ total number of loci; $\mathrm{Cj}$ : number of common alleles between the pairs of accessions $\mathrm{i}$ and $\mathrm{i}$, and $\mathrm{p}_{\mathrm{j}}=\mathrm{a}_{\mathrm{j}} / \mathrm{A}$, in which: $\mathrm{a}_{\mathrm{j}}$ : total number of alleles of the locus $\mathrm{j}$; A: total number of alleles.

Cluster analyses were processed to generate a dendrogram using the algorithm UPGMA (unweighted pair group method with arithmetic mean).

Statistical analyses were performed on the Genes version 2007.0.0 computer program, developed in the Bioinformatics/Bioagro laboratory of the Universidade Federal de Viçosa, Minas Gerais, Brazil.

\section{RESULTS AND DISCUSSION}

Sixty accessions derived from the grapevine germplasm collection of Embrapa Semiárido in Juazeiro, state of Bahia, Brazil, were genotyped for the first time using seven reference microsatellite markers (THIS et al., 2004). This set of accessions is represented by cultivars and selections derived from different breeding programs. The largest group is composed by Brazilian cultivars from the breeding programs of Instituto Agronômico de CampinasIAC ('A Dona', 'Aurora' or 'IAC 77526', 'Isaura', 'Juliana', 'Patricia', 'Paulistinha' and the root stock cultivars 'IAC 313' and 'IAC 766') and Embrapa Uva e Vinho ('Moscato Embrapa', 'BRS Rubea', 'BRS Clara', 'BRS Linda', 'BRS Morena' and 'BRS Lorena').

All the loci used amplified in a satisfactory manner in almost all the cultivars and were multiallelic. Eighty-nine alleles were obtained, ranging from 11 (VVS2) to 14 (VVMD31 and VVMD7), with an average and effective number of 12.7 alleles per locus (Table 1). This value is higher than those already mentioned by other authors working with grapevine accessions of diverse geographic origins. Almadanim et al. (2007) obtained a mean of 8.17 alleles per locus, Vouillamoz et al. (2006) observed a mean value of 11.9 alleles per locus and Martín et al. (2003) found 11 alleles per locus. Lamboy and Alpha (1998), analyzing the diversity of 110 accessions belonging to 21 species of Vitis and 4 hybrids found 24.4 alleles per locus, a greater quantity than that observed in this study.

The most frequent alleles in each locus were VVMD5 - 238 (25.8\%), VVMD7 - 239 (21.6\%), VVMD27 - 185 (26.7\%), VVMD31 - $212(29.2 \%)$, VVS2 -133 (20.0\%), VrZAG62 - 189 (35.0\%) and VrZAG79 - 255 (21.7\%) (Figure 2). Forty-three alleles $(48.3 \%)$ were rare, with frequencies of less than $5 \%$. The frequency of rare alleles is in agreement with that observed by Martín et al., (2003). On the other hand, it was less than the quantity of $73 \%$ of rare alleles mentioned by Lamboy and Alpha (1998) upon analyzing a group of 110 taxonomically broader accessions.

Expected heterozygosity $\left(\mathrm{H}_{\mathrm{e}}\right)$ ranged from $81.8 \%$ (VrZAG62) to $88.1 \%$ (VrZAG79), with a mean of $84.8 \%$ (Table 1). This value was greater than other $\mathrm{H}_{\mathrm{e}}$ results already obtained by Martínez et al. (2006) (81\%), Martín et al. (2003) (80.6\%) and Lamboy and Alpha (1998) (62.5\%).

The high number of heterozygotes obtained in this study may be explained by the predominance of hybrids, with many interspecific hybrids among them, combining alleles of different species of Vitis. High heterozygosity of the cultivated grapevine is a consequence of selection throughout the domestication process and growing in favor of hybrid vigor which confers desirable characteristics such as high production and larger size of bunches and berries (LAMBOY and ALPHA, 1998).

The values obtained for polymorphic 
information content were less than those of expected heterozygosity. All the loci may be considered highly informative (PIC $>70 \%$ ). The loci VrZAG79 and VVMD7 were the most informative, with a PIC of 87.1 and $86.1 \%$, respectively, while VrZAG62 was the least informative, with a PIC value of $80.1 \%$ (Table 1). In contrast, the locus VrZAG62 was the most informative ( $\mathrm{PIC}=88 \%$ ) according to Martinez et al., (2006) and VVMD7 was the least informative ( $\mathrm{PIC}=70.5 \%$ ), according to Martín et al. (2003).

The allelic combinations of the seven loci were sufficient to differentiate 55 genotypes. Correspondences were observed between the allelic profiles of the accessions 'Aurora' and 'IAC 77526', 'A Dona' and 'Himoront', 'Júpiter' and 'CG 26858', 'Ferlongo' and 'Moscatel Nazareno', and 'A1581' and 'A1105' (Table 2). Among them, the denomination 'IAC 77526' designates the number of selection for the 'Aurora' cultivar, and therefore they constitute a case of synonymy. The other genotypes constitute distinct cultivars and they may therefore be mistakenly identified in the collection, with the need for repeating the analyses using a greater number of microsatellite molecular markers.

Genetic similarities were observed which ranged from 0 to $100 \%$ among the accessions assessed (Figure 1), with a mean similarity of $22 \%$ of common alleles, below the values mentioned in previous studies by other authors. Lopes et al. (1999; 2006), studying the diversity of the grapevine grown in Portugal, obtained $36 \%$ and $38 \%$ of common alleles respectively, while Sefc et al. (1998) reported $40 \%$ and $43 \%$ of common alleles in the group of cultivars of $V$. vinifera and root stock from Austria respectively.

The formation of a large group with 52 accessions may be observed on the dendrogram (Figure 1) which was separated at the level of 57\% of genetic dissimilarity from the cultivars Lake Emerald, Moscato Noir, 'IAC 313' and 'IAC 766' root stock, and from the group composed by the accessions 'Blue Lake', 'Seyve Villard 12327', 'Seyve Villard 12375' and 'Regner'. The cultivar of German origin 'Regner' has an allele in common in all the loci with 'Seyve Villard 12375', showing a parent/progeny relationship between them. This shows that the denomination of this accession is incorrect in this collection because it did not correspond to the Regner cultivar (Vitis vinifera $\mathrm{L}$.) whose pedigree is 'Luglienca Bianca' $\mathrm{X}$ 'Gamay Precoce'. The root stock from Instituto Agronômico de Campinas exhibited the greatest diversity in relation to the other grapevine accessions (91\%) and a genetic similarity between them of $37 \%$.
Fatahi et al. (2003) also observed the formation of a group which gathered root stock from four different American species.

When a dissimilarity of $50 \%$ in the dendrogram was considered, five groups were formed and diverse accessions were isolated, not being included in any group.

'Aurora' and 'IAC 77526' exhibited the same allelic profile and formed the first group, with a mean dissimilarity of $84 \%$ in relation to the other accessions.

The second group was composed of seven selections from the INTA, Argentina and by the cultivars Júpiter, Ângelo Pirovano, BRS Linda, Marroo Seedless, Dominga, Marengo Pirovano, Paulistinha and Sovrano Pirovano. 'Dominga', a cultivar of Spanish origin, whose pedigree was unknown, exhibited a genetic similarity of $65 \%$ with the cultivar Marengo Pirovano and $42 \%$ with 'Sovrano Pirovano', sharing an allele in at least six markers, which may show a possible parent/progeny relationship between 'Delizia de Vaprio' and these three cultivars.

The third group was composed of six accessions, among them, two hybrids from the University of Arkansas, 'Reliance' and 'Mars', and two Brazilian hybrids, 'Patricia' and 'BRS Lorena'. The accession called 'Roni Redi', also belonging to this group, has an unknown origin and pedigree, but shared an allele in six loci with the cultivar Beni Fugi, showing possible common parentage, and it also exhibited high genetic similarity with the American hybrids 'Bordo', 'Mars', 'Reliance' and 'Vênus', and it is possible that 'Ontario' is present in its genetic background.

The fourth group included only two accessions: 'California' and the hybrid 'Juliana', developed by the Instituto Agronômico de Campinas, with a $51 \%$ similarity between them.

The fifth group was made up of nineteen accessions, which may be separated into seven distinct subgroups.

'A1105', 'A1581', 'A1118' and 'Saturn' formed a subgroup; they have at least one allele in common in the seven loci studied, showing a genetic relatedness. The selections 'A1581' and 'A1105' exhibited the same allelic profile; both are seedless grapes that may be distinguished in the field by the color of their berries: 'A 1105 ' has white berries and 'A1581' has dark berries. In Spain, the cultivars 'Carrasquín' and 'Prieto Picudo Tinto' also exhibited identical genotypes, in spite of having significant morphological and isoenzymatic differences (MARTÍN et al., 2003) with the authors affirming 
that a greater number of microsatellite markers must be added to distinguish the genotypes.

Another subgroup was composed by hybrids from Instituto Agronômico de Campinas: 'Isaura', 'Muscat Saint Vallier' and 'Beni Fugi'. 'Isaura', whose pedigree is unknown, and 'Muscat Saint Vallier' shared at least one allele in all seven loci, indicating genetic relatedness between them.

'A Dona', 'Himoront', 'BRS Clara' and 'BRS Rubea' formed a subgroup. 'A Dona' and 'Himoront' exhibited the same allelic profile, proving to be the same genotype. Genetic relatedness was observed between the cultivars Perlona and 'A Dona', with a genetic similarity of $49 \%$; they have the cultivar Muscat of Alexandria in their genetic background. The high genetic similarity between the cultivars 'BRS Clara' and 'BRS Rubea', developed by Embrapa Uva e Vinho, was not expected as they had distinct genealogies (CAMARGO et al., 2010), indicating an error in denominating 'BRS Rubea'.

The accessions 'Damarim', 'Dacari', 'Moscatuel', 'Emperatriz' and 'Baviera' were confirmed as synonymies for the selections ' $\mathrm{CG}$ 40016', 'CG 102024', 'CG 102295', 'CG 28467' and 'CG26916' respectively, developed by Gargiulo in the INTA, Argentina. The selections of Gargiulo were divided into two groups; they have the cultivar Thompson Seedless in common in their genetic background. The selections 'CG26916', 'CG28467' and 'CG87908', exhibited an allele in common with the cultivar Thompson Seedless in at least six loci, showing a parent/progeny relationship between them.
The accessions 'Vênus', 'Feal', 'CG 351', 'Perlona', 'Dona Maria', 'Tampa', 'Moscato Embrapa', 'BRS Morena' and 'Neptune' were not included in any group, when $50 \%$ of genetic dissimilarity was considered as the cutoff point.

A separation of the accessions according to their geographic origin, or even according to their use, was not observed: table grapes or wine production, or morphological traits, as, for example, the color of the berries. Martín et al. (2003), studying 272 grapevine accessions from the Iberian Peninsula in Portugal and Spain, did not find a separation according to the region of origin. Martínez et al. (2006) evaluating the diversity of 'Criollas' grapevines from Peru and Argentina, also did not observe separation of groups according to the country of origin. Nevertheless, Dangl et al. (2001) obtained separation of cultivars of $V$. vinifera from the USDA Germplasm Repository according to their geographic origin. In this study, genealogy was the primordial factor for formation of groups, grouping accessions with similar genetic backgrounds, as may be observed in the group that joined the accessions that had 'Thompson Seedless' as a parent in the first or second generation. These results obtained allow better understanding regarding the diversity, origin and genetic relatedness among the accessions, providing subsidies to grapevine genetic breeding programs in Brazil, as well as correct identification of the cultivars for the purposes of genetic certification, traceability and legal protection of new cultivars.

TABLE 1- Genetic parameters of seven SSR loci evaluated in 60 grapevine accessions.

\begin{tabular}{ccccc}
\hline Locus & Alleles Number & $\mathbf{H e}^{\mathbf{1}} \mathbf{( \% )}$ & PIC $^{\mathbf{2}} \mathbf{( \% )}$ & $\mathbf{F}_{\text {maximum }}{ }^{3}$ \\
\hline VVMD5 & 12 & 83.9 & 81,9 & 25.8 \\
VVMD7 & 14 & 87.4 & 86,1 & 21.6 \\
VVMD27 & 13 & 83.6 & 81,7 & 26.7 \\
VVMD31 & 14 & 83.3 & 81,4 & 29.2 \\
VVS2 & 11 & 85.9 & 84,3 & 20.0 \\
VrZAG62 & 12 & 81.8 & 80,1 & 35.0 \\
VrZAG79 & 13 & 88,1 & 87,1 & 21.7 \\
\hline Média & 12,7 & 84,8 & 83,2 & \\
\hline
\end{tabular}

${ }^{1}$ Expected heterozygosity; ${ }^{2}$ polymorphic information content $;{ }^{3}$ Maximum frequency of alleles . 


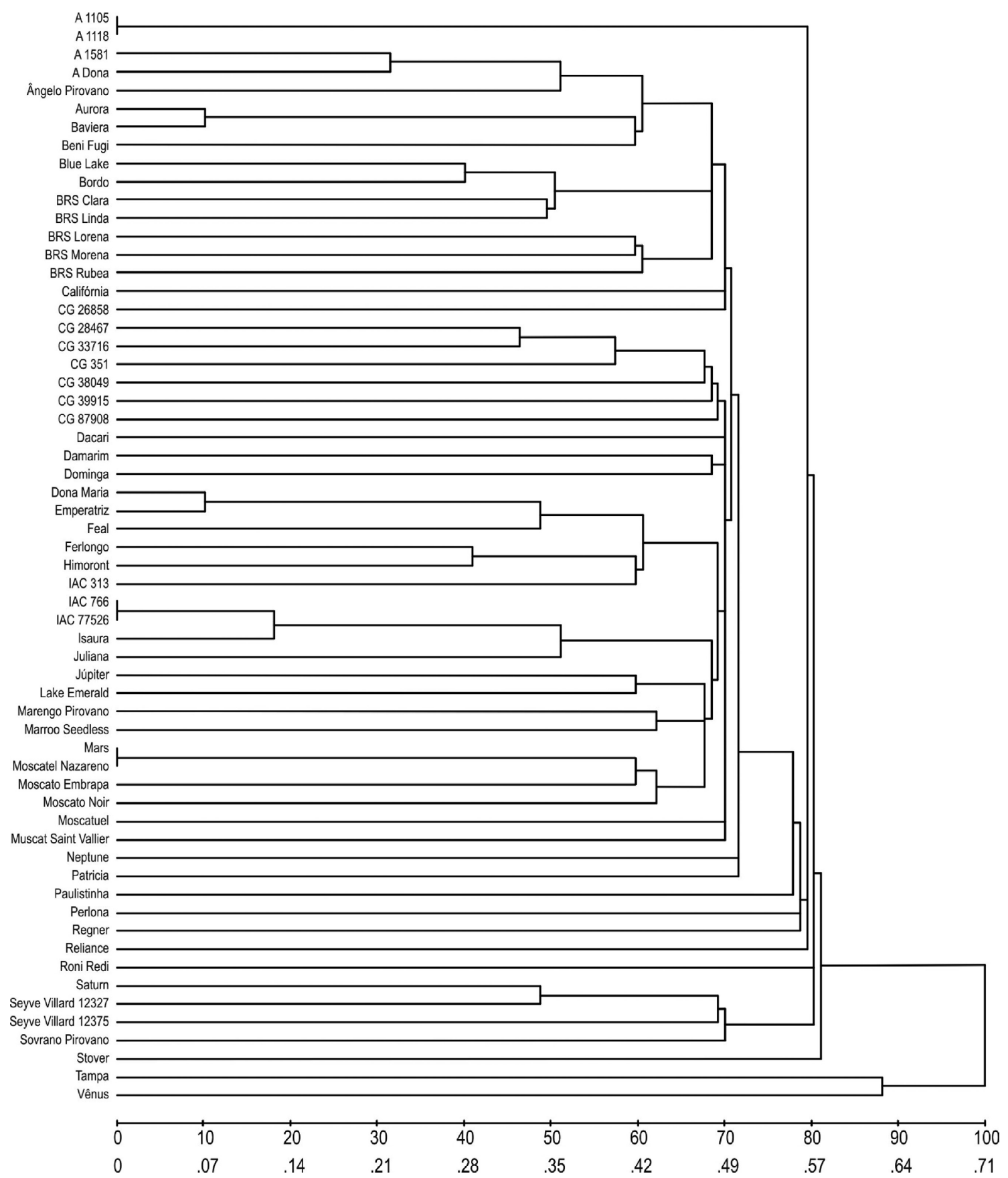

FIGURE 1 - Dendogram representing the clustering of 60 grapevine accessions by UPGMA method using seven microsatellite markers. 

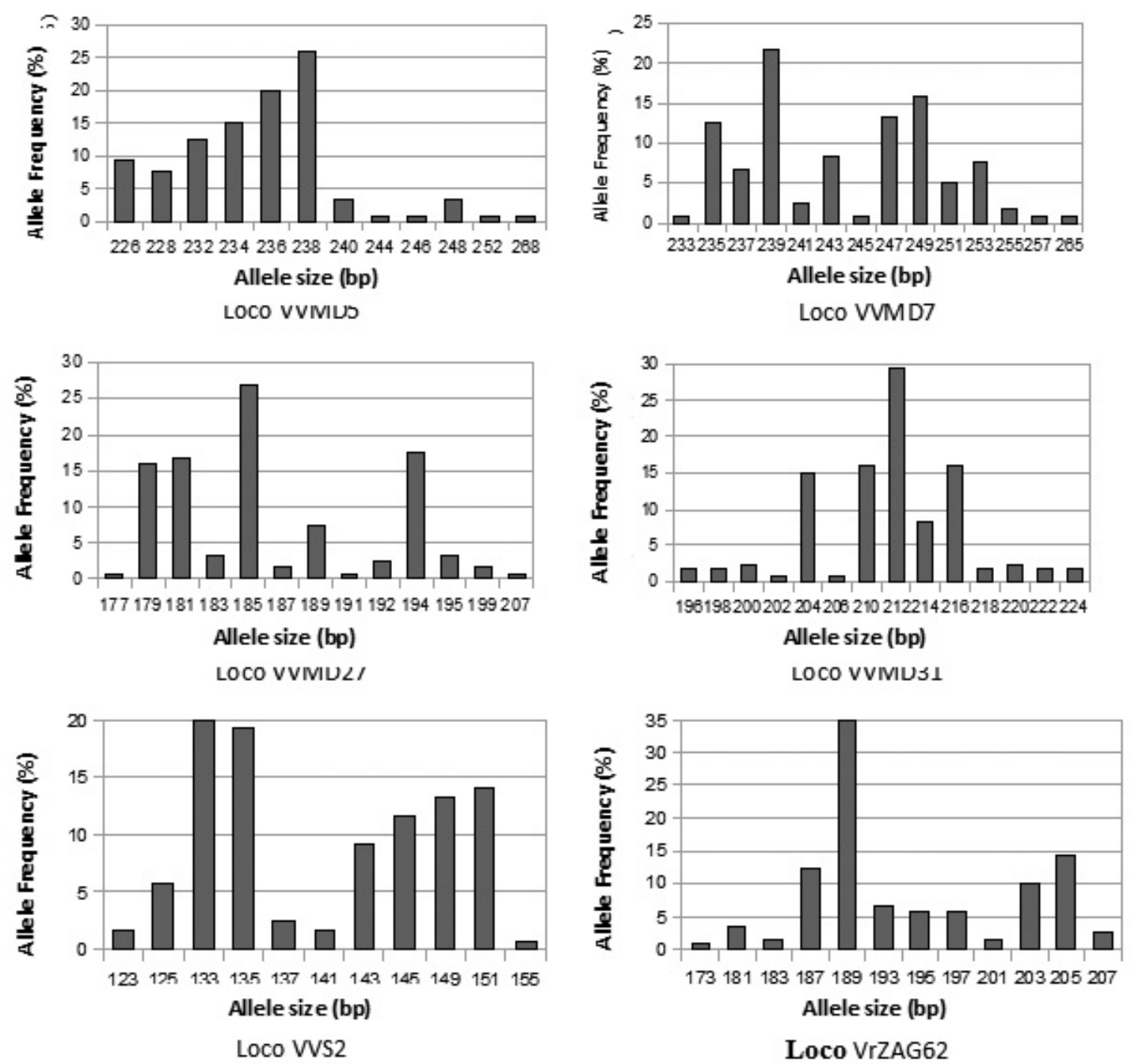

Loco VrZAG62

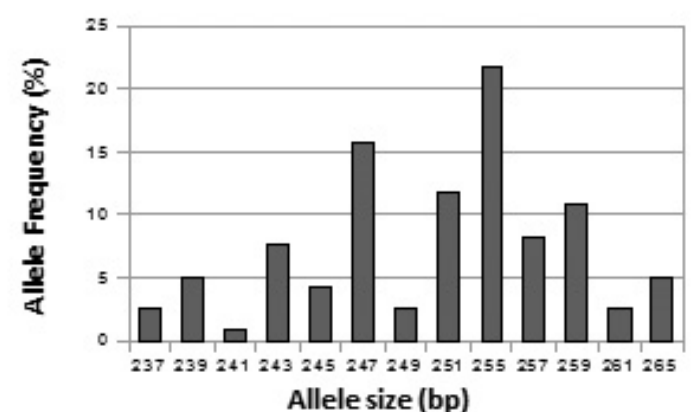

Loco VrZAG79

FIGURE 2- Frequency of alleles of seven microsatellite loci in 60 accessions of grapevine. 
TABLE 2- Accessions which results obtained were based on pedigree SSR analysis.

\begin{tabular}{lll}
\hline \multicolumn{1}{c}{ Accession } & \multicolumn{1}{c}{ Pedigree } & \multicolumn{1}{c}{ Results } \\
\hline Angelo Pirovano & Chasselas Rose X Muscat Hamburg & Muscat Hamburg rejected as parental \\
Beni Fugi & Golden Muscat X Kuroshio & Parents confirmed \\
BRS Morena & Marroo Sds X Centennial Sds & Parents confirmed \\
BRS Rubea & Niagara Rosada X Bordo & Parents rejected \\
CG 33716 & Dattier de Beiroth X Thompson & Parents rejected \\
CG 38049 & Riesling X (Gibi X Thompson ) & Parents confirmed \\
Feal & Italia X Fernão Pires & Italia rejected as parental \\
Ferlongo & Ferral X Alphonse Lavallee & Parents rejected \\
Lake Emerald & Pixiola X Golden Muscat & Golden Muscat confirmed as parental \\
Marroo Seedless & Carolina Blackrose X Ruby & Parents confirmed \\
Mars & Island belle X A1339 & Island belle confirmed as parental \\
Moscatel Nazareno & Muscat de Hamburgo X Joao Santarem & Parents confirmed \\
Paulistinha & Niagara Branca X Sultanina & Thomson Sds confirmed as parental \\
Reliance & Ontario X Suffolk & Parents confirmed \\
Sovrano Pirovano & Frakenthal X Delizia de Vaprio & Frankenthal noir confirmed as parental \\
Tampa & Vitis smalliana O.P. X Niagara & Niagara confirmed as parental \\
Vênus & Alden X New York 46000 & Alden confirmed as parental \\
Juliana & Italia X Madalena (IAC 21-14) & Itália confirmed as parental \\
CG 26858 & Alphonse Lavalle X Thompson & Parents confirmed \\
\hline & &
\end{tabular}

\section{CONCLUSION}

1- The study of genetic diversity by means of cluster analysis by the UPGMA method allowed separation of the genotypes according to their genealogy, facilitating understanding of the genetic relatedness among them;

2- Microsatellite markers allowed identification of possible parentage for the cultivars 'Dominga', 'Isaura', 'CG 26916', 'CG28467' and 'Roni Redi', whose pedigrees are not available in the literature and databases consulted;

3- Six synonymies were confirmed: 'Aurora' and 'IAC 77526', 'Damarim' and 'CG 40016', 'Dacari' and 'CG 102024', 'Moscatuel' and 'CG 102295', 'Emperatriz' and 'CG 28467', 'Baviera' and 'CG26916'. Among them, the denominations 'Damarim', 'Dacari' and 'Baviera' constitute names not yet registered in the database consulted.

\section{ACKNOWLEDGMENTS}

The authors gratefully acknowledge research support from University of CaliforniaDavis (UC DAVIS) .

\section{REFERENCES}

AlleweldT, G.; DeTtWEIlER, E. The resources of vitis: world list of grapevine collections. $2^{\text {nd }}$ ed. Geilweilwehof, 1994.

ALMADANIM, M. C.; BALEIRAS-COUTO, M. M.; PEREIRA, H. S.; CARNEIRO, L. C.; FEVEREIRO, P.; EIRA-DIAS, J. E.; MORAISCECILIO, L.; VIEGAS, W.; VELOSO, M. M. Genetic diversity of the grapevine (Vitis vinifera L.) cultivars most utilized for wine production in Portugal. Vitis, Siebeldingen, n.46, p.116-119, 2007.

BOTSTEIN, D.; WHITE, R. L.; SKOLNICK, M.; DAVIS, R. W. Construction of a genetic linkage map in man using restriction fragment length polymorphisms. American Journal of Human Genetics, Chicago, n.32, p.314-331, 1980. 
BORGES, R. M. E.; GONÇALVES, N. P. da S.; GOMES, A. P. de O.; AlveS, E. O. dos. Phenotypic divergence among table grapes accesses in the Brazilian Semi-Arid. Pesquisa Agropecuária Brasileira, Brasília, n.43, p.1.025-1.030. 2008.

BOWERS, J.; DANGL, J. S.; MEREDITH, C. P. Development and characterization of additional microsatellite DNA markers for grape. American Journal of Enology and Viticulture, Davis, v.50, n.3: 243-246, 1999.

BOWERS, J.; DANGL, J. S.; VIGNANI, R.; MEREDITH, C. P.; DANGL, J. S.; VIGNANI, R.; MEREDITH, C. P. Isolation and characterization of new polymorphic simple sequence repeat loci in grape (Vitis vinifera L.). Genome, Ottawa, n.39, p.628-633, 1996.

BOWERS, J.; MEREDITH, C. P. The parentage of a classic wine grape, Cabernet Sauvignon. Nature Genetics, New York, n.16, p.84-87,1997.

CAMARGO, U. A.; MAIA, J. D. G.; RITSCHEL, P. Embrapa uva e vinho: new brazilian grape cultivars. Bento Gonçalves: Embrapa Uva e Vinho, 2010. 64 p.

CRESPAN, M. The parentage of Muscat of Hamburg. Vitis, Siebeldinger, n.42, p.193-197, 2003.

DANGL, G. S.; MENDUM, M. L.; BERNARD, H. P.; WALKER, M. A.; MEREDITH, C. P.; SIMON, C. J. Simple sequence repeat analysis of a clonally propagated species: a tool for managing a grape germoplasm collection. Genome, Ottawa, n. 44, p.432-438, 2001.

FATAHI, R.; EBADI, A.; BASSIL, N.; MEHLENBACHER, S. A.; ZAMANI, Z. Characterization of Iranian grapevine cultivars using microsatellite markers. Vitis, Sielbeldinger, n.42, p.185-192, 2003.

LAMBOY, W. F.; ALPHA, C. G. Using simple sequence repeats (SSRs)for DNA fingerprinting germplasm acessions of grape (Vitis L.) species. Journal of the American Society of Horticultural Science, Alexandria, v.123, n.2, p.182-188, 1998.

LEÃO, P. C. de S.; CRUZ, C. D.; MOTOIKE, S. Y. Genetic diversity of Brazilian wine grape germplasm collection based on morphoagronomic traits. Revista Brasileira de Fruticultura, Jaboticabal, v.32, n.4, p.1164-1172, 2010.
LEÃO, P. C. de S. ; CRUZ, C. D.; MOTOIKE, S. Y. Genetic diversity of table grape based on morphoagronomic traits. Scientia Agrícola, Piracicaba, n.68, p.42-49, 2011.

LODHI, M. A.; YE, G. N.; WEEDEN, N. F.; REISCH, B. I. A simple and efficient method for DNA extraction from grapevine cultivars and Vitis species. Plant Molecular Biology Reporter, Athens, v.12, p.6-13, 1994.

LOPES, M. S.; SANTOS, M. R. dos; DIAS, J. E. E.; MENDONÇA, D.; MACHADO, A. da C. Discrimination of Portuguese grapevines based on microsatellite markers. Journal of Biotechnology, Amsterdam, n.127, p.34-44, 2006.

LOPES, M. S.; SEFC, K. M.; EIRA DIAS, E.; STEINKELLNER, H.; MACHADO, M. L. da C. The use of microsatellites for germoplasm management in a Portuguese grapevine collection. Theoretical and Applied Genetics, Berlin, n.99, p.733-739, 1999.

MARTÍN, J. P.; BORREGO, J.; CABELLO, F.; ORTIZ, J. M. Characterization of Spanish grapevine cultivar diversity using sequence-tagged microsatellite site markers. Genome, Ottawa, n.46, p.10-18, 2003.

MARTÍNEZ, L. E.; CAVAGNARO, P. F.; MASUELLI, R. W.; ZÚÑIGA, M. SSR-based assessment of genetic diversity in South American Vitis vinifera varieties. Plant Science, Limerick, n.170, p.1036-1044, 2006.

MEREDITH, C. P.; BOWERS, J. E.; RIAZ, S.; HANDLEY, V.; BANDMAN, E. B.; DANGL, G. $\mathrm{S}$. The identity and parentage of the variety known in California as Petite Sirah. American Journal of Enology and Viticulture, Davis, v.50, n.3, p.236242, 1999.

NEI, M. Molecular evolutionary genetics. New York: Columbia University Press, 1987. p.106-107.

SEFC, K. M.; REGNER, F.; GLÖSSL, J.; STEINKELLNER, H. Genotyping of grapevine and rootstock cultivars using microsatellite markers. Vitis, Siebeldingen, v.37, n.1, p.15-20, 1998. 
SEFC, K. M.; REGNER, F.; TURETSCHEK, E.; GLÖSSL, J.; STEINKELLNER, H. Identification of microsatellite sequences in Vitis riparia and their applicability for genotyping of different Vitis species. Genome, Ottawa, v.42, p.367-373, 1999.

THIS, P.; JUNG, A.; BOCCACCI, P.; BORREGO, P.; BOTTA, R.; COSTANTINI, L.;CRESPAN, M.; DANGL, G. S.; EISENHELD, C.; FERREIRAMONTEIRO, F.; GRANDO, S.; IBÁÑEZ, J.; LACOMBE, T.; LAUCOU, V.; MAGALHÃES, R.; MEREDITH, C. P.; MILANI, N.; PETERLUNGER, E.; REGNER, F.; ZULINI, L.; MAUL, E. Development of a standard set of microsatelitte reference alleles for identification of grape cultivars. Theoretical and Applied Genetic, New York, v. 109, p. 1448-1458, 2004.
THOMAS, M. R.; SCOTT, N. S. Microsatellite repeats in grapevine reveal DNA polymorphisms when analysed as sequence-tagged sites (STSs). Theoretical and Applied Genetics, Zuchter, n.86, p.985-990, 1993.

VITIS INTERNATIONAL VARIETY CATALOGUE. Database search. Cultivar name.Disponível em: http://www.vivc.de/. Acesso em 10/05/2011.

VOUILLAMOZ, J. F.; MCGOVERN, P. E.; ERGUL, A.; SÖYLEMEZOGLU, G.; TEVZADZE, G.; MEREDITH, C. P.; GRANDO, S. Genetic characterization an relationships of traditional grape cultivars from Transcaucasia and Anatolia. Plant Genetic Resources, Cambridge, v.4, n.2, p.114$158,2006$. 